\title{
Tingkat Pengetahuan dan Sikap Dokter Umum di RS JUWITA Bekasi Mengenai \\ Resusitasi Jantung Paru (RJP) untuk Menangani End of Life pada Pasien \\ Knowledge and Attitude Among Medical Doctors in JUWITA Bekasi Hospital \\ Towards Lung Cardiac Resuscitation (LCR) to Address End of Life \\ in Patients
}

\author{
Azhar Muhamad Ghifari ${ }^{1}$, Ferryal Basbeth ${ }^{2}$, Arsyad $^{3}$, Qomariyah Sachrowardi ${ }^{4}$ \\ ${ }^{1}$ Student Faculty of Medicine, YARSI University, Jakarta \\ ${ }^{2}$ Department of Forensic, Faculty of Medicine, YARSI University, Jakarta \\ ${ }^{3}$ Department of Islamic Religion, Faculty of Medicine, YARSI University, Jakarta \\ ${ }^{3}$ Department of Physiology, Faculty of Medicine, YARSI University, Jakarta \\ Jalan Letjen. Suprapto, Cempaka Putih, Jakarta 10510 \\ Telephone (021) 4206674, 4206675, 4206676 \\ Correspondence Email: muhamadghifari25@gmail.com
}

\begin{abstract}
Abstrak
Beberapa penelitian menunjukkan angka keberhasilan Resusitasi Jantung Paru (RJP) hingga saat ini masih buruk. RJP berhasil dilakukan pada pembedahan jantung, henti jantung yang disaksikan kangsung, irama jantung yang tidak beraturan (ventricular fibrillation atau tachycardia). Penelitian lain menunjukkan tindakan RJP sering bertentangan dengan keinginan pasien. Padahal setiap keputusan harus dibuat tanpa paksaan dan dengan kesadaran penuh, sebaliknya tindakan RJP sering dilakukan pada waktu penderita dalam keadaan incompetency. Tujuan penelitian ini untuk mengetahui Tingkat Pengetahuan dan Sikap Dokter Umum di RS JUWITA Bekasi Mengenai RJP pada Akhir Kehidupan Pasien (end of life) dan Tinjauannya Menurut Islam. Metode. Penelitian ini merupakan studi deskriptif cross sectional menggunakan kuesioner, dan menggunakan teknik pengambilan sampel non-probabilitas. Hasil. Pengetahuan responden mengenai RJP ditemukan 30 responden menjawab dengan benar indikasi dan tujuan RJP, tetapi hanya 2 responden yang mengetahui angka keberhasilan RJP. Selain itu, ditemukan 18 responden yang melakukan RJP pada kasus death on arrival $(D \circ A)$. Penilaian sikap responden menemukan bahwa 16 responden bersedia mentalkinkan pasien pada akhir kehidupan mereka, dan 18 responden akan melakukan informed consent sebelum malakukan tindakan RJP. Tingkat pengetahuan dan sikap responden mengenai RJP di RS Juwita Bekasi tergolong dalam kategori yang baik menurut studi ini. Simpulan. Tingkat pengetahuan dan sikap dokter mengenai resusitasi jantung paru di RS Juwita Bekasi memiliki nilai yang baik, hal ini sejalan dengan "pengetahuan yang baik akan memiliki sikap yang baik".
\end{abstract}

Kata kunci: Resusitasi Jantung Paru, End of Life, Tingkat Pengetahuan dan Sikap

\section{Abstract}

Several studies showed that up until recently the success rate of Cardio Pulmonary Resuscitation (CPR) is still low. CPR is successfully performed on heart surgery, witnessed cardiac 
arrest directly, and irregular heart rhythms (ventricular fibrillation or tachycardia). Other studies show that CPR actions often conflict with the wishes of patients. Even though every decision must be made without coercion and with full awareness, the CPR procedure is often done when the patient is in the state of incompetency. The purpose of this study was to determine the level of knowledge and attitudes of general medical practitioners in JUWITA Bekasi Hospital towards CPR at the end of patient life (end of life) and its review according to Islam

Method. The research is a descriptive cross-sectional study using a questionnaire, and using nonprobability sampling techniques. Results. The assessment of respondents' knowledge of CPR found that 30 respondents knew the indications and objectives of CPR, but only 2 respondents knew the success rate of CPR. Moreover, the study found that 18 respondents did CPR on the case of death on arrival (DoA). The assessment of the attitudes of respondents found that 16 respondents would lead the talkin in the end of their patients' lives, and 18 respondents would obtain informed consent before doing CPR actions. The level of knowledge and attitudes of respondents regarding CPR at Juwita Hospital Bekasi is good according to this study. Conclusions. The level of knowledge and attitudes of doctors regarding cardio pulmonary resuscitation in Juwita Hospital Bekasi has good score, this is in line with "good knowledge will breed a good attitude".

Keywords: Cardio Pulmonary Resuscitation, End of Life, Knowledge and Attitude

\section{Pendahuluan}

Resusitasi jantung paru adalah suatu tindakan pertolongan yang dilakukan kepada korban yang mengalami henti napas dan henti jantung. Keadaan ini bisa disebabkan karena korban mengalami serangan jantung (heart attack), tenggelam, tersengat arus listrik, keracunan, kecelakaan dan lain-lain. Pada kondisi napas dan denyut jantung berhenti maka sirkulasi darah dan transportasi oksigen berhenti,sehingga dalam waktu singkat organorgan tubuh terutama organ fital akan mengalami kekurangan oksigen yang berakibat fatal bagi korban dan mengalami kerusakan. Organ yang paling cepat mengalami kerusakan adalah otak, karena otak hanya akan mampu bertahan jika ada asupan gula/glukosa dan oksigen. Jika dalam waktu lebih dari 10 menit otak tidak mendapat asupan oksigen dan glukosa maka otak akan mengalami kematian secara permanen. Kematian otak berarti pula kematian si korban. Oleh karena itu GOLDEN PERIOD (waktu emas) pada korban yang mengalami henti napas dan henti jantung adalah dibawah 10 menit. Artinya dalam watu kurang dari 10 menit penderita yang mengalami henti napas dan henti jantung harus sudah mulai mendapatkan pertolongan. Jika tidak, maka harapan hidup si korban sangat kecil. Adapun pertolongan yang harus dilakukan pada penderita yang mengalami henti napas dan henti jantung adalah dengan melakukan resusitasi jantung paru / CPR (Lalenoh, 2010; American Heart Association, 2005).

Beberapa penelitian angka keberhasilan Resusitasi Jantung Paru (RJP) hingga saat ini masih buruk. RJP berhasil dilakukan pada pembedahan jantung, henti jantung yang disaksikan kangsung, irama jantung yang tidak beraturan (ventricular fibrillation atau 
tachycardia). Penelitian lain menunjukkan tindakan RJP sering bertentangan dengan keinginan pasien. Padahal setiap keputusan harus dibuat tanpa paksaan dan dengan kesadaran penuh, sebaliknya tindakan RJP sering dilakukan pada waktu penderita dalam keadaan incompetency (Qomariah, Basbeth, 2013).

Bagaimana jika tindakan intervensi medis yang dilakukan memberikan sedikit manfaat? Siapakah yang harusnya memutuskan untuk dilakukannya tindakkan tersebut? Ketika kehidupan seseorang digambarkan dengan penyakit lanjut, ketergantungan penuh dengan orang lain, dimensia, sedangkan keuntungan yang didapat dari tindakan RJP ternyata tidak adekuat dan tidak sesuai yang diharapkan?. Memberikan hak sepenuhnya kepada pasien untuk memutuskan tindakan yang akan dilakukan tidak akan menyelesaikan masalah. Ketika permasalahan yang terkait dengan kematian dan koma menjadi sangat sulit maka perlu ketegasan tentang tujuan sebenarnya yang akan dicapai (Hilberman et al., 1997). Jika resusitasi adalah sia-sia maka setiap kerugian yang terjadi akan membawa manfaat yang tidak menguntungkan / membahayakan keseimbangan, sehingga melakukan tindakan tanpa tujuan yang berguna adalah suatu hal yang tidak efektif dan tidak akan berhasil (Ardagh, 2000).

Murphy dan Finucane mengusulkan definisi kesia-siaan operasional sebagai perlakuan yang sangat tidak mungkin untuk berhasil dan banyak orang awam maupun kalangan professional menganggap bahwa hal tersebut tidak sepadan dengan biaya (Ardagh, 2000; Gillon, 1997).

The American Thoracic Society mengadopsi makna kesia-siaan ini lebih konservatif, namun definisinya lebih samarsamar, dimana dikatakan bahwa intervensi medis tersebut dikatakan sia-sia jika sudah sangat tidak mungkin untuk menghasilkan makna kehidupan. Oleh karena itu The American Thoracic Society memberikan definisi kesia-siaan berasal dari campuran keduanya antara kuantitatif (sangat tidak mungkin) dan kualitatif (bermakna untuk bertahan hidup) Gillon, 1997).

American Heart Association mengambil definisi kualitatif kesia-siaan secara ekstrem, dikatakan bahwa RJP adalah sia-sia ketika tidak ada yang selamat seperti yang dilaporkan pada sebuah penelitian yang didesain dengan baik, dan dibuat untuk mempertimbangkan bahwa tindakan RJP adalah tidak sia-sia. Definisi dangkal yang dikemukakan oleh American Heart Association ini tampaknya untuk mendukung bahwa usaha RJP pada situasi-situasi tersebut akan membawa lebih banyak ruginya daripada keuntungannya, dimana definisi kesia-siaan ini adalah konsisten dengan definisi kesia-siaan yang ada yaitu tidak ada manfaatnya (American Heart Association, 2005).

Tomlinson dan Brody mengakui bahwa untuk menyatakan suatu tindakan atau intervensi medik harus melibatkan keseimbangan yang kompleks antara ketidakpastian dan kewajiban akan tanggung jawab. Schneiderman dan Jacker telah mempelajari tentang makna kesia-siaan dan membuat definisi kuantitatif dari sia-sia yang membutuhkan kepastian bahwa intervensi tersebut minimal 100 kali gagal digunakan. Hal ini menunjukkan bahwa tindakan tersebut tidak memiliki suatu kejelasan tertentu, sehingga diperlukan diskusi yang mendalam dengan pasien atau keluarga untuk mengevaluasi keuntungan dan beban atau tangunggung jawab 
yang masih tersisa (Beauchamp, Childress, 1994; Gillon, 1997).

Jarang sekali pasien bertahan hidup setelah dilakukan RJP dimana henti jantung yang timbul disebabkan oleh penyakit selain jantung atau disfungsi organ. Harapan hidup pasien setelah dilakukan tindakan RJP sangat buruk (<5\%) ketika henti jantung terjadi pada pasien dengan gagal ginjal, kanker (kecuali dengan penyakit yang minimal), atau AIDS; dan dengan tidak adanya penyakit penyebab yang irreversible, diikuti dengan trauma, perdarahan, hipotensi yang berkepanjangan atau pneumonia. Dibatasinya pelaksanaan RJP telah meningkatkan derajat harapan hidup pasien sebesar $10,5 \%$ setelah tindakan RJP dimana 710\% lainnya ditahan untuk dilakukan RJP (Hilberman et al., 1997).

\section{Al-Qur'an menunjukkan bahwa setiap} makhluk yang bernyawa (ruh) pasti mati. Banyak ayat di Al Quran yang mengingatkan tentang kematian.

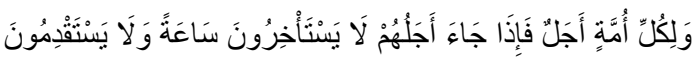

Artinya: "Tiap-tiap umat mempunyai batas waktu; maka apabila telah datang waktunya mereka tidak dapat mengundurkannya barang sesaat pun dan tidak dapat (pula) memajukannya." (QS. Al A'raf: 34).

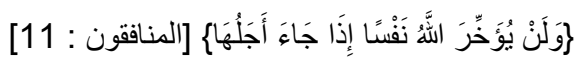

Artinya: "Dan Allah sekali-kali tidak akan menangguhkan (kematian) seseorang apabila. datang waktu kematiannya. Dan Allah Maha Mengetahui apa yang kamu kerjakan" (QS. Al Munafiqun: 11).

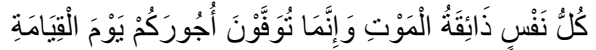

“Tiap-tiap yang bernyawa akan merasakan mati. Dan sesungguhnya pada hari kiamat sajalah disempurnakan pahala kalian”. (Surat Ali 'Imran: 185).

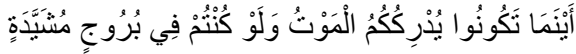

"Di mana pun kalian berada, kematian akan mendapatkan kalian, kendatipun kalian berada di dalam benteng yang tinggi lagi kokoh" (Surat An Nisa': 78)

Bahkan dalam sebuah hadist dikatakan

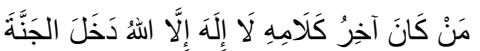

"Barangsiapa yang akhir perkataannya sebelum meninggal dunia adalah 'lailaha illallah', maka dia akan masuk surga" (HR. Abu Daud. Dikatakan shohih oleh Syaikh Al Albani dalam Misykatul Mashobih no. 1621)

\section{Bahan dan Metoda Penelitian}

Penelitian ini merupakan penelitian kualitatif. Bertujuan untuk memverifikasi tingkat pengetahuan dokter dan sikap dokter dalam menangani End of Life pada pasien dengan RJP (Resusitasi Jantung Paru). Populasi dari penelitian ini adalah seluruh Dokter jaga IGD RS Juwita Bekasi yang pernah mendapat pelatihan mengenai RJP (Resusitasi Jantung Paru). Pengambilan sample dilakukan dengan cara memberikan kuisioner dengan pertanyaaan yang sudah tersedia, sample tersebut akan diberikan kepada 30 Dokter di RS Juwita Bekasi yang pernah melakukan RJP kepada pasien. Penelitian ini menggunakan teknik penetapan sampling secara non-probability. Tehnik nonprobability sampling akan ditetapkan secara purposive, yaitu sample diambil sesuai kriteria yang sudah ditentukan. Pengumpulan data dilakukan dengan memberikan kuesioner kepada responden, dalam hal ini responden adalah Dokter Umum di RS Juwita Bekasi. Dan ditarik kesimpulan dari hasil kuesioner yang sudah di jawab oleh responden. 


\section{Hasil Penelitian}

Pengetahuan responden mengenai RJP ditemukan 30 responden menjawab dengan benar indikasi dan tujuan RJP, tetapi hanya 2 responden yang mengetahui angka keberhasilan RJP, dan ditemukan 12 responden yang melakukan RJP pada kasus death on arrival (DoA). 24 responden menjawab bila RJP dilakukan futile atau sia-sia maka responden akan melakukan sendiri atau memanggil keluarga untuk membimbing pasien mentalkinkan kalimat syahadat.

Hasil penelitian mengenai sikap responden menunjukkan hampir semua responden setuju dan sangat setuju untuk membimbing pasien dalam akhir hidupnya dengan kalimat tauhid atau memanggil keluarga untuk melakukan hal tersebut.

Tabel 1. Nilai Responden dalam Menjawab Kuesioner Pengetahuan

\begin{tabular}{|c|c|c|}
\hline Pertanyaan & $\begin{array}{l}\text { Responden } \\
\text { Menjawab Benar }\end{array}$ & $\begin{array}{l}\text { Responden } \\
\text { Menjawab Salah }\end{array}$ \\
\hline \multicolumn{3}{|l|}{ Kuesioner Pengetahuan } \\
\hline $\begin{array}{l}\text { Apakah pasien diluar penyakit jantung di Intensive Care Unit } \\
\text { mendapatkan tindakan RJP? }\end{array}$ & 24 & 6 \\
\hline Apakah Resusitasi Jantung Paru dilakukan atas indikasi Sosial? & 25 & 5 \\
\hline Apakah anda tahu tujuan dilakukannya RJP ? & 30 & 0 \\
\hline $\begin{array}{l}\text { Apakah dokter berhasil menyelamatkan nyawa pasien setelah } \\
\text { dilakukan RJP? }\end{array}$ & 18 & 12 \\
\hline Jika dilakukan RJP futile, bagaimana tindakan anda sebagai dokter ? & 24 & 6 \\
\hline Berapa menurut anda angka keberhasilan RJP ? & 2 & 28 \\
\hline Total & 123 & 55 \\
\hline
\end{tabular}

Tabel 2. Nilai Responden dalam Menjawab Kuesioner Sikap

\begin{tabular}{|c|c|c|c|c|c|}
\hline Pertanyaan & SS & $\mathrm{S}$ & $\mathrm{R}$ & TS & STS \\
\hline $\begin{array}{l}\text { Apakah saudara bersedia untuk mentalkinkan (Laa llaha Illallah) pasien } \\
\text { pada akhir hidupnya? }\end{array}$ & 16 & 13 & 1 & - & - \\
\hline $\begin{array}{l}\text { Apakah anda bersedia melakukan Informed Consent kepada pasien dan } \\
\text { keluarga pasien untuk melakukan RJP sesuai indikasi yang sudah } \\
\text { ditetapkan? }\end{array}$ & 18 & 12 & - & - & - \\
\hline $\begin{array}{l}\text { Apakah anda bersedia untuk melakukan RJP diluar indikasi yang sudah } \\
\text { ditentukan? }\end{array}$ & 1 & - & 7 & 12 & 10 \\
\hline $\begin{array}{l}\text { Apakah anda bersedia memanggil keluarga pasien ketika pasien dalam } \\
\text { keadaan the edge of critical death? }\end{array}$ & 18 & 11 & 1 & - & - \\
\hline $\begin{array}{l}\text { Apakah anda bersedia untuk melakukan RJP sesuai Indikasi yang sudah } \\
\text { ditentukan? }\end{array}$ & 19 & 11 & - & - & - \\
\hline $\begin{array}{l}\text { Jika saudara dalam keadaan henti nafas dan henti jantung yang sesuai } \\
\text { indikasi RJP, apakah saudara bersedia untuk dilakukan RJP? }\end{array}$ & 6 & 10 & 7 & 5 & 2 \\
\hline Total & 76 & 57 & 16 & 17 & 12 \\
\hline
\end{tabular}




\section{Diskusi}

Dari hasil tersebut, diketahui bahwa responden memiliki nilai yang berbeda antara satu responden dengan responden lainnya. Dalam hal pengetahuan, nilai dari responden tidak begitu jauh berbeda. Hanya sedikit dari responden yang memiliki pengetahuan yang buruk. Namun, hal ini tidak berhubungan dengan sikap responden.

Dilihat dari tabel 1.1, para responden dapat menjawab pertanyaan nomor 3 mengenai tujuan dilakukannya resusitasi jantung paru sebanyak 30 responden menjawab benar. Namun, hal ini tidak berimbang dengan pengetahuan responden mengenai angka keberhasilan RJP itu sendiri, yakni sebanyak 28 responden menjawab salah. Dengan data yang ada pada tabel 1.1, maka sebanyak 26 responden memiliki nilai yang baik $(40-50)$, nilai cukup $(30-40)$ dimiliki oleh 1 responden, nilai kurang $(20-30)$ dimiliki oleh 2 responden dan terdapat 1 responden dengan nilai sangat kurang $(10-20)$.

$\mathrm{Hal}$ ini dapat dipengaruhi oleh keaktifan responden dalam mengikuti seminar tentang resusitasi jantung paru. Pengetahuan atau kognitif merupakan domain yang sangat penting untuk terbentuknya tindakan seseorang (Wawan dan Dewi, 2011).

Sedangkan pada hasil dari sikap, nilai dari responden berbeda-beda, tetapi secara garis besar sikap dalam melakukan talkin atau memanggil keluarga untuk melakukan talkin kepada pasien pada akhir hidupnya adalah setuju dan sangat setuju. Perbedaan diluar itu mungkin dipengaruhi oleh karena pengalaman responden terhadap tindakan resusitasi jantung paru.
Pengalaman responden dalam menangani pasien gawat darurat, ternyata mempengaruhi hasil dari penilaian sikap responden. Hal ini dapat dibuktikan dengan nilai responden dalam mengisi kuesioner yang dimana nilai yang didapat oleh 6 responden menunjukan nilai yang sangat baik (25 - 30), sebanyak 23 responden memiliki nilai yang baik (20 - 25) dan 1 responden memiliki nilai yang cukup $(15-20)$.

Dalam penelitian Gyung Park (2015), tentang The effect of cardiopulmonary resuscitation training on cardiopulmonary resuscitation knowledge, attitude, and self efficacy of nursing students. Hasil dari penelitian tersebut menyatakan bahwa pelatihan RJP bagi mahasiswa keperawatan secara signifikan meningkatkan pengetahuan, sikap dan self efficacy dalam kaitannya dengan RJPR.

Mengacu pada hasil, dengan melihat nilai pengetahuan dan sikap dari responden itu sendiri. Didapatkan hasil bahwa, hubungan antara tingkat pengetahuan dan sikap dokter di RS Juwita Bekasi ternyata berhubungan. Nilai pengetahuan responden yang baik di pengaruhi oleh responden itu sendiri dalam mengikuti seminar atau workshop mengenai kegawatdaruratan, dalam hal ini mengenai resusitasi jantung dan paru. Berdasarkan hal ini maka, tingkat pengetahuan yang kurang tidak mempengaruhi sikap responden akan tindakan resusitasi jantung paru. Tingkat pengetahuan seseorang mempengaruhi akan sikap dari responden itu sendiri.

\section{Simpulan dan Saran}

Berdasarkan hasil penelitian ini, dapat ditemukan bahwa ada hubungan antara tingkat pengetahuan dan sikap dokter mengenai RJP 
untuk menangani End of Life pada pasien di RS Juwita Bekasi.

\section{Daftar Pustaka}

American Heart Association, 2005. Journal of American Heart Association Circulation. Journal of American Heart Association Circulation; p. 6-11.

Ardagh M, 2000. Futility has no utility in resuscitation medicine. Journal of Medical Ethics; 26;396-399

Beauchamp TL, Childress JF 1994. Principles of biomedikal ethics [4thed]. New York: Oxford University Press.

Gillon R, 1997. "Futility"--too ambiguous and pejorative a term? Journal of Medical Ethics; 23;339-340
Gillon R, 1997. "Futility"--too ambiguous and pejorative a term? Journal of Medical Ethics; 23;339-340

Hilberman M, Kutner J, Parsons D, Murphy DJ, 1997. Marginally effective medikal care: ethical analysis of issues in cardiopulmonary resuscitation (CPR). Journal of Medical Ethics; 23:361-7

Lalenoh DC 2010. Bantuan Ventilasi pada Kegawatdaruratan. Simposium Kegawatdaruratan Medis \& P2KB IDI; Hotel Peninsula; Jan 26.

Sachrowardi Q, Ferryal B, 2013. Isu dan Dilema Dalam Bioetika. Jakarta: AIFI dan Universitas YARSI.

Youngner SJ, 1988. Who defines futility? JAMA; 260:2094-5. 